\title{
Ifta' and Fatwa in the Muslim World and the West
}

\author{
Zulfiqar Ali Shah
}

London: International Institute of Islamic Thought, 2014. 192 pages.

In his review of Maha Elkaisy-Friemuth's Gods and Humans in Islamic Thought: Abdul-Jabbār, Ibn Sina and al-Ghazāli (Abingdon: Routledge, 2006), Sajjad Rizvi (2008) identifies three paths proposed by three influential medieval thinkers as characterizing the interconnected nature of intellectual inquiry in Islam: Abd al-Jabbar (d. 1025), regarded as representing the kalām 
tradition, Ibn Sina (d. 1037) of the philosophical orientation, and al-Ghazali (d. 1111) of the Sufi tradition. If Rizvi had accurately added the juridical or jurisprudential dimension to Elkaisy-Friemuth's perspective, his review would have panoramically captured the essence of Islam's intellectual tradition. The elegant book under review, Ifta and Fatwa in the Muslim World and the West, edited by Zulfiqar Ali Shah, has taken care of that major omission in what may be described as a virtually all-encompassing look at emerging concerns

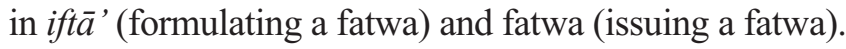

The book features an introduction by the editor and eight chapters by scholars in the various foci of the subject covered. The introduction situates the book's subject in a historical context and exposes its indebtedness to the seminar convened during July 2011 by the International Institute of Islamic Thought's (IIIT) Summer Institute for Scholars, which addressed this topic. The editor attributes the emergence of consensus on the chaotic nature of the contemporary processes of both ift $\bar{a}$ ' and fatwa to the seminar. He then identifies the intellectual skills required for analytical reasoning, as well as the broad general knowledge of the fields relevant to the cultural contexts of their verdicts, as the strength that characterized the excellent performance of scholars in fatwa formulation and issuance from the rise of the Abbasids in 750 to the fall of Andalusia in 1492. Conversely, contemporary knowledge is fragmented into specializations and sub-specializations, all of which can hardly be mastered by one scholar or group of scholars. The editor, who engages critically with various issues and concerns involved in the contemporary formulation and issuance of fatwa, also provides a brief description of each chapter's subject. However, the word al-fiqh al-istidlālī (demonstrative fiqh) is wrongly rendered as fiqh alistighlālī (p. 10).

Abdullah Saeed's chapter, "Textual Challenges to the Death Penalty for Apostasy in Islam and the Question of Freedom of Religion," is quite interesting in terms of the concept of religious freedom, the importance of religious freedom, and the reality in Muslim-majority countries today. He exposes the intrigues that sometime define the attitude and dispositions of Islamic scholars to some sensitive issues. For example, he reveals how some of Shaykh Taha Jabir al-Alwani's colleagues dissuaded him from publishing his Lā Ikrāha fí al-Din (There is No Coercion in Matters of Religion) on the grounds that since at that time he was the president of IIIT, such a book may negatively affect the institute's image and color other Muslims' perception of him. Saeed is at his best when he demystifies the concept of apostasy, the question of reliability in hadith texts, and the idea of consensus, as well as support for religious free- 
dom in the Islamic tradition. However, there is an ambiguity in the sentence “... under them, capital punishment for political crimes seems have to become the norm"( p. 22). This may be seen as merely a problem of transposition and "seems have to" may therefore be corrected as "seems to have." The fact that the report concerns a past historical event may arguably necessitate rendering "seems" as "seemed."

Imad-ad-Dean Ahmad's "Shuratic Ifta ' : The Challenge of Fatwa Collectivization" is a synthetic methodology constituted by a combination of the traditional concept of shüra (consultation) with the modern scientific methodologies of peer review and innovations in online communication. According to the author, this approach has the potential to facilitate the use of the latest technological and scientific developments to preserve the principles of jurisprudence. He analyzes the intricacies involved in a historical dimension and discusses the obstacles and objections to collectivization. He illustrates his argument with the issues of calendar reform and embryonic stem cell research.

Concerning the former, he reveals how the Fiqh Council of North America (FCNA) pursued this reform via the parliamentary mode of collective ift $\bar{a}$ ' in 2006. Remarkably, it reversed itself within forty-eight hours of adopting the astronomer's proposal that the date of the new month be based on the astronomical new moon before sunset at Makkah and embraced the proposal to adopt the convention of the new moon's birth at noon GMT. Within one year, it discarded that proposal and adopted the European Union for Fatwa's position that the conjunction must materialize before sunset in Makkah and the moon must set after sunset in Makkah. These frequent changes have been described as a product of "the politicization of ift $\bar{a}$ " to which a parliamentary approach is susceptible" (p. 40). His analysis of the embryonic stem cell research is equally interesting. The author claims that "the best scholars were those who not only possessed the keen intellect required for clear original and analytical reasoning, but who had a broad general knowledge..." (p. 34). It makes a grammatically better read to either eliminate the word "who" or substitute it with the word "also."

In his "Minority Fiqh as Deliberative Ijtihād: Legal Theory and Practice," Abdessamad Belhaj provides a good insight into the theoretical setting of deliberative $i j t i h \bar{a} d$ in Islamic law. He articulates the three main perspectives of modern scholarship on the question: (1) the position that considers ijmā' as the source of deliberative ijtiha $\bar{d}$, (2) the perspective that places a premium on the role of fatwa-giving committees as a novel form of collective ijtihäd, and (3) the perspective that perceives deliberative ijtihād as being embodied in a legislative assembly. More interestingly, the author highlights the peculi- 
arities of the perspectives of each of the three most distinguished contemporary contributors to the scholarship of deliberative ijtihād, namely, Al-Alwani, Yusuf al-Qaradawi, and Abd Allah ibn Al-Shaykh al-Mahfuz ibn Bayyan. There is no doubting the fact that this chapter is written in a sophisticated prose. I shall illustrate here with only five examples of the same pattern where the author consistently fails to reflect the emphasis on the Arabic letter ya': Page/line 53/29: al-jamā' '̀yah (al-jamā'iyyah); 55/4: al-aqallìyāt (alaqalliyyāt); 55/33 al-istithnā '̄yah (al-istithnā'iyyah); 56/21: Ta'sīsìyah (Ta sisìyyah); and 57/11 al-Dinìyah (al-Diniyyah).

In "Ordering Religion, Organizing Politics: The Regulation of the Fatwa in Contemporary Islam," Alexandre Caeiro examines the proliferation of voices currently clamoring for regulating the formulation of fatwas in the Muslim world. He identifies as probably the most notable call in this regard "The Amman Message of July 2005, when some 200 Muslim scholars outlined, at the request of King Abdallah II of Jordan, the conditions necessary for the issuance of fatwas" (p. 73). He adds that there have since been international conferences, scholarly books, and organized sessions about the need to curtail the spread of abnormal fatwas in various parts of the world. He seems to be at his best where he characterizes the current trend in fatwa formulation with "The Narrative of Chaos" and alludes to the nature of fatwas and counterfatwas that trailed Saddam Hussein's invasion of Kuwait, the emergence in the 1990s of radical movements acting in the name of religions, as well as the recent Arab Spring. He draws essentially on al-Qaradawi's "Alternative Account," which he analyzes meaningfully. There are, however, a few linguistic errors that must be addressed later. For instance, the author writes "Chaos or disorder are rather imprecise metaphors" (p. 75) instead of "Chaos or disorder is rather an imprecise metaphor."

"Fatwa in the Era of Globalization," by Moustafa Kassem, is one of the best organized and systematically structured chapters. The author lives up to the expectation with regard to his subject. He provides good definitions of the term fatwa, offers a satisfactory analysis of the traditional applications of Islamic jurisprudence, and analyzes the basis for religious edicts as well as distinguishing characteristics of the fatwa. The role of technology and social media, the possibility of regulation, and the nature of fatwas in the private sector are among the themes that receive adequate attention in the chapter. The phrase "...issues that have mislead...many people" (p. 94) may be corrected as "misled."

Keneth L. Honerkamp's “Al-Qushayri's Fatwa and His Risālah: Their Relevance to Intra-Islamic Dialog Today" is another well-crafted chapter. The 
author's introduction situates Al-Qushayri, along with his fatwa and Risālah, in a good context. He provides a meaningful description of the fatwa, the life story of al-Qushayri in a social context, and enumerates his scholarly works and critical engagement with his immediate environment. What follows is essentially a review of the Risālah and a list of al-Qushayri's teachers and notable students. At the end of the chapter, the reader receives from Honerkamp a pen-portrait of al-Qushayri as a versatile and encyclopedic scholar whose scholarship is not restricted to the ethical, theological, and legal domains, but has a panoramic coverage. However, the quality of this impressive essay may be enhanced by correcting the following errors: "compliment each other" ( $p$ 106) (complement); "principle mosque" (p. 108) (principal); mistranslation of iddi ' $\bar{a}$ ' as "pretense" (p. 111) (self-proclamation); and mistranslation of riya $\bar{a}$ ' as "hypocrisy" (p. 111) (eyeservice). These mistranslations may be traceable to Alexander Knysh, whose translation the author claims to have relied upon and also certifies as "faithful to the original text in form and content" (p. 118). There also are few instances of the wrong use of fatwa akhlāqi (pp. 105 and 118) (fatwā akhläqiyyah).

In "The Guardians of the Islamic Marriage Contract and the Search for Agency in Twelver Shi'a Jurisprudence," Vinay Khetia focuses on the debates over whether a mature virgin of sound mind is allowed to get married without her $w \bar{a} l \vec{\imath}$ s permission. He reveals the different rulings in this regard and that the works of demonstrative jurisprudence are central to the question involved. He associates two opinions with contemporary jurists: that the $w \bar{a} l \vec{\imath}$ s consent is required and that it is not. The second one seems to be less popular. He enumerates virtually all the twenty-three father's independence traditions associated with the four major Imami hadith compendiums, but only dwells extensively on the reports by al-Khu'i and al-Ruhani, specific details of which he provides in a lengthy analysis.

The high point is the author's analysis of the power dynamics in the Islamic family structure. Few things are, however, wrong with the chapter. One, it contains no instance of correct transliteration of any Arabic word involving an emphasized letter yā' as in istiqlālìyah (p. 130) (istaqlāliyyah). Two, "principle sources" (p. 136) (principal). Three, "the result is by and large deemed

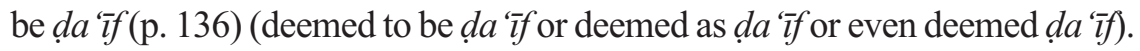
Four, "with regards to Sa'dan" (p. 137) (with regard to). Five, the author's statement (some of the intricacies involved in $i j t i h \bar{a} d$, which includes but is not limited to..."(p. 130) (which include but are not limited to). Six, "demonstrative jurisprudence" was incorrectly rendered as "al-fiqh al-istidlall" (p. 129) (al-fiqh al-istidlāli) Seven, "Do not seek the counsel" (p. 131) is inaccu- 
rately rendered as "lā tasta'marū" (lā tasta'mirū). Eight, "malakat nafasah $\vec{a}$ " (p/1 135/10) (nafsahā). Nine, "examiningf" (p. 130) (examining). Ten, "leaving the period of the Seventh Imam remaining in between" (p. 137) : eliminate the superfluous "remaining" and the hyphenate "in-between."

Abdulaziz Sachedina's "Islam, Healthcare, and Spirituality" closes the book with a good account on the linkage between health and moral wellbeing. Relying on appropriate Qur'anic injunctions, he examines Islamic spirituality and illustrates with various experiences in the Islamic legal tradition. He exposes the linkages between physical wellbeing and religious, moral, cultural, and other dimensions of human life. More impressive is the author's account of the international community's growing embrace of the Islamic perspectives in bioethics. He however mistranslated the Arabic word sihhah as "sound or health" (p. 173). He is correct on "health" but wrong on "sound," which can be rendered into Arabic as "șahīh" and therefore connotes "healthy." Similarly, he mistranslated the word saläma as "sound or health" (p. 173). He is wrong in both instances, for salama means "safety" and can only be related to health when conjugated as a qualifier "salim" meaning "sound" or "healthy."

This book contains materials of varying quality, which makes it worthy of a central place in any rich and sophisticated library whether in the Muslim world or the West. The editor and chapter contributors deserve plaudits for their painstaking efforts.

Saheed Ahmad Rufai 